\title{
Penerapan RAD pada Aplikasi E-Learning Lembaga Bimbingan Belajar Gold Generation
}

\author{
Usman Nurhasan $^{1}$, Muhammad Mujahid ${ }^{2}$, Ferina Bayu Sukmadewi $^{\mathbf{3}}$ \\ 1,2,3 Jurusan Teknologi Informasi, Politeknik Negeri Malang \\ E-mail: $\underline{* 1}$ usmannurhasan@ @olinema.ac.id, ${ }^{2}$ muhammadmujahid14@ gmail.com, \\ ferinabayu@gmail.com
}

\begin{abstract}
Abstrak -Perkembangan teknologi informasi saat ini telah membantu proses kehidupan manusia dalam menjalankan kegiatannya. Dalam kehidupan di masa mendatang, teknologi informasi merupakan sektor yang paling dominan. Teknologi banyak berperan dalam bidangbidang antara lain: bidang kesehatan, bidang pemerintahan bahkan bidang pendidikan. Dalam dunia pendidikan peranan teknologi informasi sangat dibutuhkan salah satunya oleh Lembaga Bimbingan Belajar Gold Generation sebagai peningkatan kualitas pelayanan yang diberikan lembaga tersebut. Selama ini pengerjaan tryout dan tugas masih dalam bentuk lembaran soal dan belum terekam dalam database. Hal ini menyulitkan untuk admin dan pengurus lembaga dalam mengelola nilai dan mengoreksi hasil tugas mereka. Selain itu pengajar kesulitan dalam memantau siswa yang mereka ajar. Istilah lain yang makin poluper saat ini ialah e-learning yaitu satu model pembelajaran dengan menggunakan media teknologi komunikasi dan informasi khususnya internet. Dengan adanya aplikasi e-lerning yang terhubung langsung oleh database akan mempermudah admin dan pengurus lembaga bimbingan belajar dalam mengelola nilai dan mengoreksi hasil tugas para siswa dan demi terwujudnya pelayanan yang lebih baik, serta memudahkan peserta didik dengan bahan/materi pelajaran. Berdasarkan hal tersebut, dibuatlah aplikasi "Aplikasi E-Learning Lembaga Bimbingan Belajar Gold Generation Berbasis Website”. Aplikasi ini diharapkan mampu membantu dalam pengelolaan nilai dan mengoreksi hasil tugas siswa di Lembaga Bimbingan Belajar Gold Generation.
\end{abstract}

Kata Kunci - pendidikan; e-learning; tryout; tugas; nilai tugas

\begin{abstract}
The development of information and technology has helped people to do their activity. In future living, information and technology will be the most dominant sector. Technology takes part in most of the aspects such education. Technology's role is urgently needed, the example is Gold Generation Tutoring Agency as their service quality improvement. During this time tryout and tasks is done in a paper and not recorded on a database. It complicates the agency officers to manage the students' grade and their tasks. And tutors find themselves in difficult situation in monitoring their students. Another popular name at the moment is E-Learning, it is one of learning process models that utilize media of information and technology communication especially internet. By the existence of e-learning that is directly connected to a database will ease the admin and the officers of the tutoring agency to manage the students grade and correct their task results, and not only for better service, but also for easing the students with lesson materials. According to the things mentioned above, "Web-based E-Learning Application of Gold Generation Tutoring agency" is made. This application is expected to help in managing students grade and correcting their tasks in Gold Generation Agency
\end{abstract}

Keywords - education; e-learning; tryout; task result

\section{PENDAHULUAN}

Perkembangan teknologi informasi saat ini telah membantu proses kehidupan manusia dalam menjalankan proses kegiatannya. Teknologi informasi adalah segala cara atau alat yang yang terintegrasi yang digunakan untuk menjaring data, mengolah dan mengirimkan atau menyajikan secara elektronik menjadi informasi dalam berbagai format yang bermanfaat bagi pemakainya [1]. 
Dalam kehidupan di masa mendatang, teknologi informasi dan telekomunikasi merupakan sektor yang paling dominan. Teknologi banyak berperan dalam bidang-bidang antara lain: bidang kesehatan, bidang pemerintahan bahkan bidang pendidikan [2]. Semakin canggih teknologi yang digunakan, maka semakin mudah dan cepat kegiatan yang dilakukan. Dengan adanya teknologi ini dapat memudahkan dalam mengelola data dengan tujuan untuk mendapat informasi yang akurat dan mudah diakses oleh client.

Dalam dunia pendidikan peranan teknologi informasi itu sangat dibutuhkan salah satunya oleh Lembaga Bimbingan Belajar Gold Generation sebagai peningkatan kualitas pelayanan yang diberikan lembaga tersebut. Selama ini pengerjaan tryout dan tugas masih dalam bentuk lembaran soal dan belum terekam dalam database. Hal ini menyulitkan untuk admin dan pengurus lembaga dalam mengelola nilai dan mengoreksi hasil tugas mereka. Selain itu pengajar kesulitan dalam memantau siswa yang mereka ajar. Dengan adanya teknologi informasi akan dapat memudahkan admin dan pengurus lembaga bimbingan belajar dalam mengelola nilai dan mengoreksi hasil tugas para siswa dan demi terwujudnya pelayanan yang lebih baik. Selain itu pengajar akan lebih mudah dalam memberikan tugas kepada siswa. Istilah lain yang makin poluper saat ini ialah e-learning adalah teknologi informasi untuk mengaktifkan siswa dan pengajar untuk berinteraksi belajar mengajar kapanpun dan dimanapun. E-Learning adalah pembelajaran interaktif yang berkomunikasi melalui instrumen yang berbeda menggunakan Internet [3]. Melalui E-Learning, belajar tidak lagi dibatasi oleh ruang dan waktu. Belajar dapat dilakukan kapan saja dan dimana saja. Hal ini mendorong peserta didik untuk melakukan analisis dan sintesis pengetahuan, menggali, mengolah dan memanfaatkan informasi, menghasilkan tulisan, informasi dan pengetahuan sendiri [4]. Salah satu perangkat e-learning yang sangat penting peranannya adalah Learning Management System (LMS). LMS adalah suatu aplikasi perangkat lunak (software) untuk keperluan kegiatan proses belajar mengajar dan kegiatan yang terhubung secara online maupun offline [5]. LMS menggunakan teknologi berbasis web untuk berkomunikasi, berkolaborasi, belajar, transfer ilmu pengetahuan, dan pembelajaran guna menambah nilai kepada peserta didik maupun karyawan di sebuah perusahaan bisnis [6].

E-learning dapat didefinisikan sebagai sebuah bentuk teknologi informasi yang diterapkan di bidang pendidikan dalam bentuk dunia maya. Istilah e-learning lebih tepat ditujukan sebagai usaha untuk membuat sebuah transformasi proses pembelajaran yang ada di sekolah atau perguruan tinggi ke dalam bentuk digital yang dijembatani teknologi internet [7]. Maka dari itu diperlukan suatu aplikasi e-lerning yang terhubung langsung oleh database guna mempermudah dan mempercepat pengolahan data. E-Learning mempermudah interaksi antara peserta didik dengan bahan/materi pelajaran. Demikian juga interaksi antara peserta didik dengan dosen/guru/instruktur maupun antara sesama peserta didik [8]. Berdasarkan hal tersebut, dibuatlah aplikasi "Aplikasi ELearning Lembaga Bimbingan Belajar Gold Generation Berbasis Website”. Aplikasi ini diharapkan mampu membantu dalam pengelolaan nilai dan mengoreksi hasil tugas siswa di Lembaga Bimbingan Belajar Gold Generation.

\section{METODE PENELITIAN}

\subsection{Tentang Lembaga}

Lembaga Bimbingan Belajar Gold Generation merupakan pendidikan non formal yang memberikan pelayanan pendidikan dengan jenjang TK, SD, SMP, SMA, dan Mahasiswa dalam mengatasi kesulitan berbagai macam pelajaran di sekolah/kampus yang berada di Kota Malang tepatnya di Jalan Panglima Sudirman Gg. Manunggal No. 10 Kecamatan Klojen, Kota Malang.

Lembaga Bimbingan Belajar Gold Generation memberikan program les yang berbasis privat dengan pengajar yang datang langsung ke rumah siswa dan program les yang berbasis kelas yang mana siswa datang ke kantor lembaga bimbingan belajar Gold Generation.

\subsection{Analisis Sistem yang Berjalan}


Dengan mempelejari sistem yang lama pada Lembaga Bimbingan Belajar dalam memberikan tugas dan mengelola data siswa, data pengajar serta nilai tugas siswa masih menggunakan excel dan google form. Sehingga seluruh data tidak saling terintegrasi dan tersimpan pada satu database. Hal ini menyebabkan sulitnya admin dan pengurus Lembaga bimbingan belajar dalam mengelola data tersebut. Dengan demikiran, dengan adanya praktek kerja lapangan ini memberikan solusi untuk membantu permasalahan yang ada dengan sebuah sistem e-learning.

\subsection{Metode Pengembangan Perangkat Lunak}

Dalam aplikasi e-learning lembaga bimbingan belajar gold generation berbasis website ini, penelitian menggunakan metode Rapid Application Development (RAD). Dalam penelitian ini memilih metode Rapid Application Development (RAD) karena tahapan-tahapannya terstruktur,pengembangan perangkat lunak dapat dilakukan dalam waktu yang cepat dengan menekankan pada siklus yang pendek. Rapid Aplication Development (RAD) adalah sebuah proses perkembangan perangkat lunak sekuensial linier yang menekankan siklus perkembangan dalam waktu yang singkat. Dalam pengembangan sistem informasi normal, memerlukan waktu minimal 180 hari, namun dengan menggunakan metode RAD, sistem dapat diselesaikan dalam waktu 30-90 hari [9].

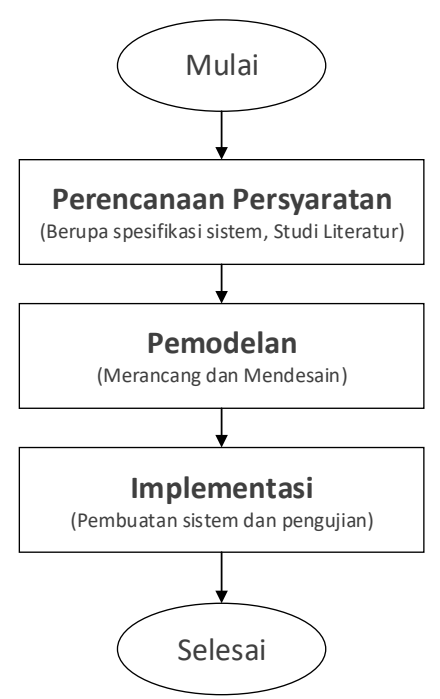

Gambar 7. Tahapan berdasarkan Rapid Application Development (RAD) Sumber : [10]

Tahapan berdasarkan Rapid Application Development (RAD) sesuai Gambar 1 adalah sebagai berikut: Pada tahapan Requirements Planning (Perencanaan Persyaratan) bertujuan untuk mengidentifikasi kebutuhan dari sistem yang akan dibangun, dengan cara mengumpulkan data dari stakeholder. Aktivitas yang dilakukan dengan melakukan pengamatan langsung dan wawancara [10].

Kemudian pada tahapan design workshop (Pemodelan) bertujuan untuk merancang arsitektur sistem secara keseluruhan. Aktivitas yang dilakukan dengan melakukan identifikasi pelaku, analisis proses dan kinerja sistem, mengidentifikasi struktur objek dan relasinya, pemodelan interaksi obyek dan behavior, dan mendesain antarmuka. Hasil yang didapatkan berupa pemodelan sistem [10].

Dan pada tahap implementasi bertujuan untuk mengimplementasikan metode, program sesuai dengan kebutuhan sistem. Hasil yang didapatkan berupa aplikasi e-learning berbasis website dengan tahapan - tahapan berdasarkan metode Rapid Application Development (RAD) [10].

\subsection{Metode Pengumpulan data}

Metode Pengumpulan data yang pertama adalah observasi. Observasi merupakan proses pengamatan sistematis dari aktivitas manusia dan pengaturan fisik dimana kegiatan tersebut 
berlangsung secara terus menerus dari lokus aktivitas bersifat alami untuk menghasilkan fakta [11]. Dalam hal ini yang akan dilakukan adalah melihat serta mempelajari permasalahan yang ada dilapangan yang erat kaitannya dengan objek yang diteliti yaitu informasi tentang pelaksanaan ujian dan tugas serta pemberian materi di Lembaga bimbingan belajar Gold Generation.

Metode Pengumpulan data yang kedua adalah wawancara. Wawancara adalah situasi berhadap-hadapan antara pewawancara dan responden yang dimaksudkan untuk menggali informasi yang diharapkan, dan bertujuan mendapatkan data tentang responden dengan minimum bias dan maksimum efisiensi [12]. Metode yang dilakukan dengan mewawancarai pengurus lembaga bimbingan belajar Gold Generation terkait kebutuhan yang akan disesuaikan dengan sistem elearning. Selain itu wawancara kepada beberapa pengajar terkait kesulitan dalam pengajaran yang bersifat manual seperti pengoreksian dan pemberian tugas kepada siswa.

\subsection{Perancangan Aplikasi}

Perencanaan pengerjaan proyek Praktek Kerja Lapangan ini melalui tahapan pembuatan deskripsi sistem berdasarkan spesifikasi sistem yang ditugaskan oleh Lembaga Bimbingan Belajar Gold Generation dan juga dilanjutkan menggunakan :

\subsubsection{Work Breakdown Structure (WBS)}

Work Breakdown Structure (WBS) hampir memiliki pengertian yang mirip dengan daftar tugas. WBS adalah sebuah cara yang digunakan untuk mendefinisikan dan mengelompokkan tugastugas dari sebuah proyek menjadi bagian-bagian kecil sehingga lebih mudah di atur. Dalam WBS terdaftar setiap pekerjaan, setiap sub-pekerjaan, setiap tonggak penting dari proyek (milestone) dan produk atau jasa yang akan diserah terimakan (deliverables) [13]. Pada Gambar 2 menjelaskan Work Breakdown Structure dibagi berdasarkan fitur tiap user yaitu admin, pengajar, dan siswa. Pada user admin terdapat fitur CRUD (Create, Read, Update, Delete) siswa, CRUD (Create, Read, Update, Delete) pengajar, CRUD (Create, Read, Update, Delete) tugas, CRUD (Create, Read, Update, Delete) jadwal, CRUD (Create, Read, Update, Delete) mata pelajaran. Sedangkan user pengajar terdapat fitur CRUD (Create, Read, Update, Delete) tugas, CRUD (Create, Read, Update, Delete) jadwal. Kemudian untuk user siswa terdapat fitur melihat tugas dan mengerjakan tugas.

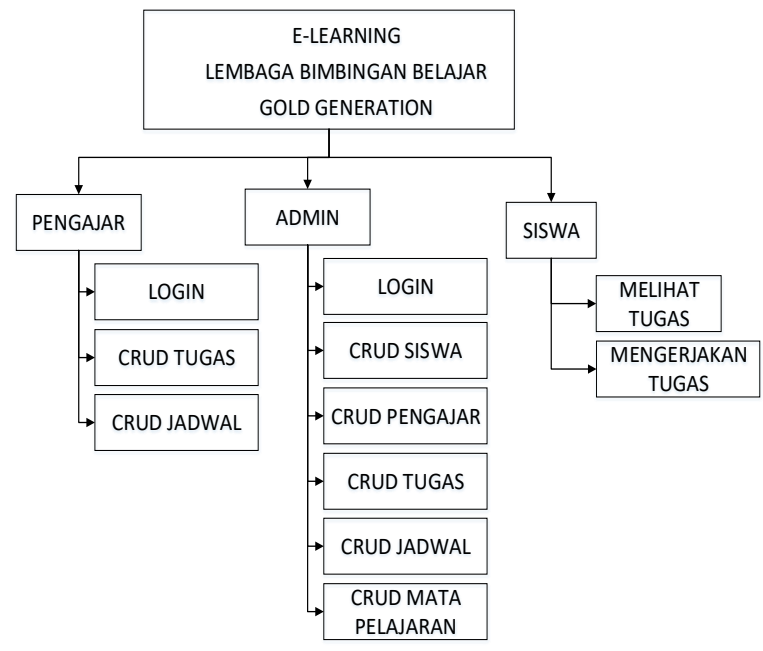

Gambar 8. Work Breakdown Structure (WBS)

\subsubsection{Use Case Diagram}

Use case diagram merupakan pemodelan untuk kelakuakn (behavior) sistem informasi yang akan dibuat. Use case mendeskripsikan iteraksi tipikal antara para pengguna sistem dengan sistem itu sendiri, dengan memberi sebuah narasi tentang bagaimana sistem tersebut digunakan [14]. Pada Aplikasi E-Learning Lembaga Bimbingan Belajar Gold Generation Berbasis Website ini 
terdapat tiga aktor yaitu admin, pengajar, dan siswa. Pada Gambar 3 tergambar use case diagram untuk user admin. Pada user admin terdapat fitur CRUD (Create, Read, Update, Delete) siswa untuk mengelola data siswa, CRUD (Create, Read, Update, Delete) pengajar untuk mengelola data pengajar, CRUD (Create, Read, Update, Delete) tugas untuk mengelola data tugas, CRUD (Create, Read, Update, Delete) jadwal untuk mengelola data jadwal, CRUD (Create, Read, Update, Delete) mata pelajaran untuk mengelola data mata pelajaran. Semua fitur tersebut dapat dilakukan ketika admin telah login pada sistem dengan menginputkan username dan password yang telah ditentukan. Username dan password admin telah ditentukan pada saat sistem dibuat.

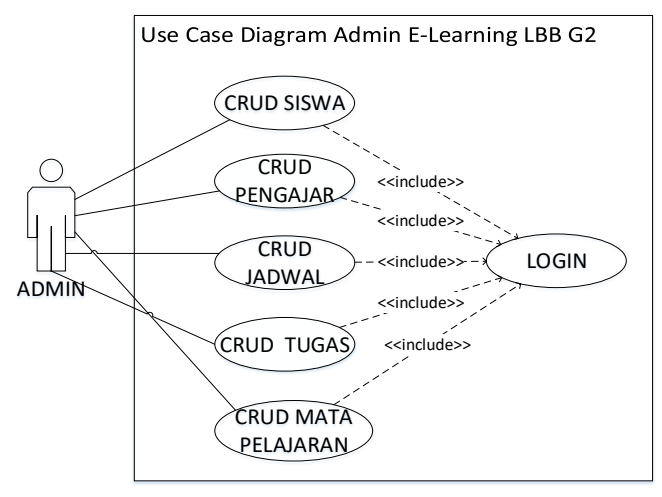

Gambar 9. Use Case Diagram Admin

Pada Gambar 4 tergambar use case diagram untuk user pengajar pada Aplikasi E-Learning Lembaga Bimbingan Belajar Gold Generation Berbasis Website. User pengajar terdapat fitur CRUD (Create, Read, Update, Delete) tugas. Tugas yang diinputkan dapat berupa pilihan ganda, essay dan tugas upload file. Selanjutnya dapat melakukan CRUD (Create, Read, Update, Delete) jadwal. Jadwal ini merupakan jadwal pengajar melakukan kegiatan mengajar kepada siswa dari hari senin hingga minggu. Berisi nama mata pelajaran beserta waktu mengajar. Semua fitur tersebut dapat dilakukan ketika pengajar telah login pada sistem dengan menginputkan username dan password yang telah ditentukan.

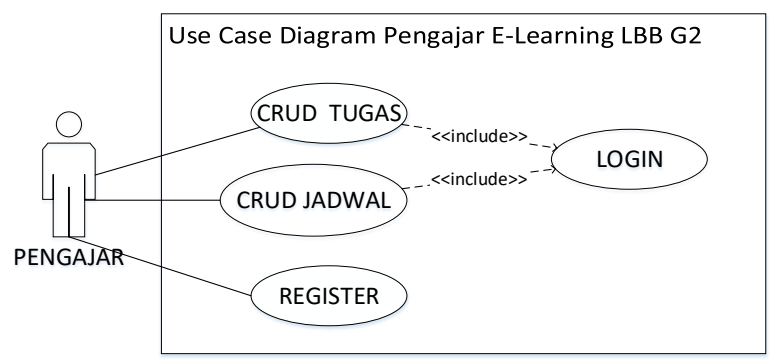

Gambar 10 Use Case Diagram Pengajar

Pada Gambar 5 tergambar use case diagram untuk user siswa pada Aplikasi E-Learning Lembaga Bimbingan Belajar Gold Generation Berbasis Website. User siswa dapat membuat akun sendiri dengan menginputkan biodata pada form yang tersedia. Ketika siswa telah membuat akun, siswa menunggu konfirmasi penyetujuan akun oleh admin lembaga, sehingga akun siswa dapat digunakan untuk login pada sistem.

Pada user siswa terdapat fitur melihat tugas dan mengerjakan tugas. Tugas yang tersedia sesuai dengan jenjang pendidikan siswa. Siswa hanya dapat mengerjakan tugas satu kali kecuali ketika tugas tersebut direset ulang oleh pengajar atau admin. Siswa tidak dapat melihat nilai dari tugas yang telah dikerjakan secara langsung. Sehingga nilai didapatkan melalui pengajar atau admin lembaga. Semua fitur tersebut dapat dilakukan ketika pengajar telah login pada sistem dengan menginputkan username dan password yang telah ditentukan 


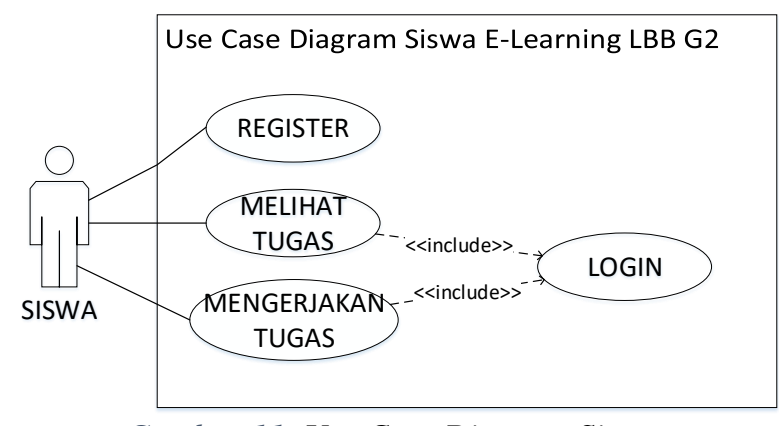

Gambar 11. Use Case Diagram Siswa

\subsubsection{Class Diagram}

Class diagram merupakan salah satu diagram utama dari UML untuk menggambarkan class atau blueprint object pada sebuah sistem. Class diagram menggambarkan struktur sistem dari segi pendifinisian kelas-kelas yang akan di buat untuk membangun sistem. Kelas memiliki apa yang disebut atribut dan metode atau operasi. Gambar 6 merupakan class diagram dari aplikasi e-elearning yang terdiri dari beberapa objek yaitu objek login, siswa, pengajar, tugas, kelas, mapel.

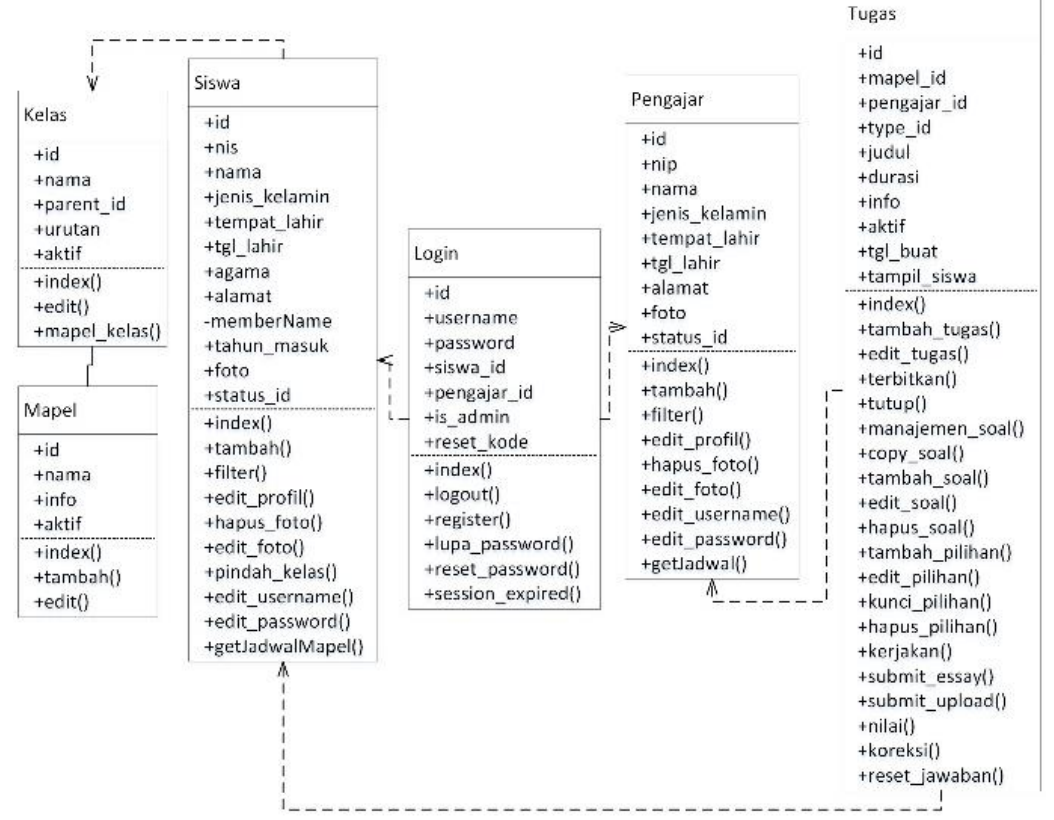

Gambar 12. Class Diagram

\subsubsection{Activity Diagram}

Activity Diagram menggambarkan workflow (aliran kerja) atau aktivitas dari sebuah sistem yang ada pada perangkat lunak yang sedang dirancang dan bagaimana masing-masing aliran berawal, keputusan yang mungkin terjadi, dan bagaimana aktivitas tersebut berakhir.

Gambar 7 merupakan activity diagram untuk menambahkan data siswa oleh admin pada sistem yang dilakukan oleh admin pada Aplikasi E-Learning Lembaga Bimbingan Belajar Gold Generation Berbasis Website. 

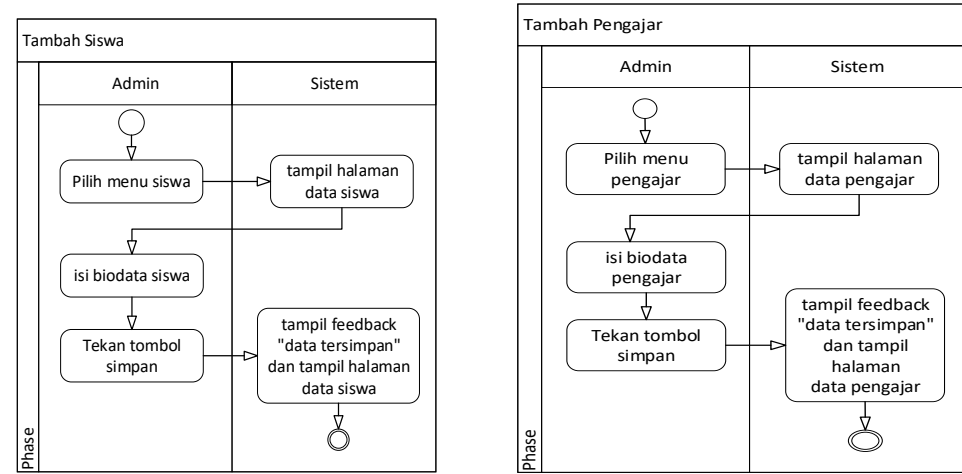

Gambar 13. Activity Diagram Tambah Siswa oleh Admin dan Tambah Pengajar

Gambar 7 merupakan activity diagram untuk menambahkan data pengajar oleh admin pada sistem yang dilakukan oleh admin pada Aplikasi E-Learning Lembaga Bimbingan Belajar Gold Generation Berbasis Website. Admin masuk pada menu pengajar kemudian sistem akan menampilkan data pengajar. Lalu admin mengisikan biodata pengajar dan menekan tombol simpan. Sistem akan menampilkan feedback yang akan tampil pada halaman data pengajar.Gambar 8 juga menampilkan activity diagram untuk membuat tugas dengan jenis pilihan ganda yang dilakukan oleh pengajar ataupun admin pada Aplikasi E-Learning Lembaga Bimbingan Belajar Gold Generation Berbasis Website.

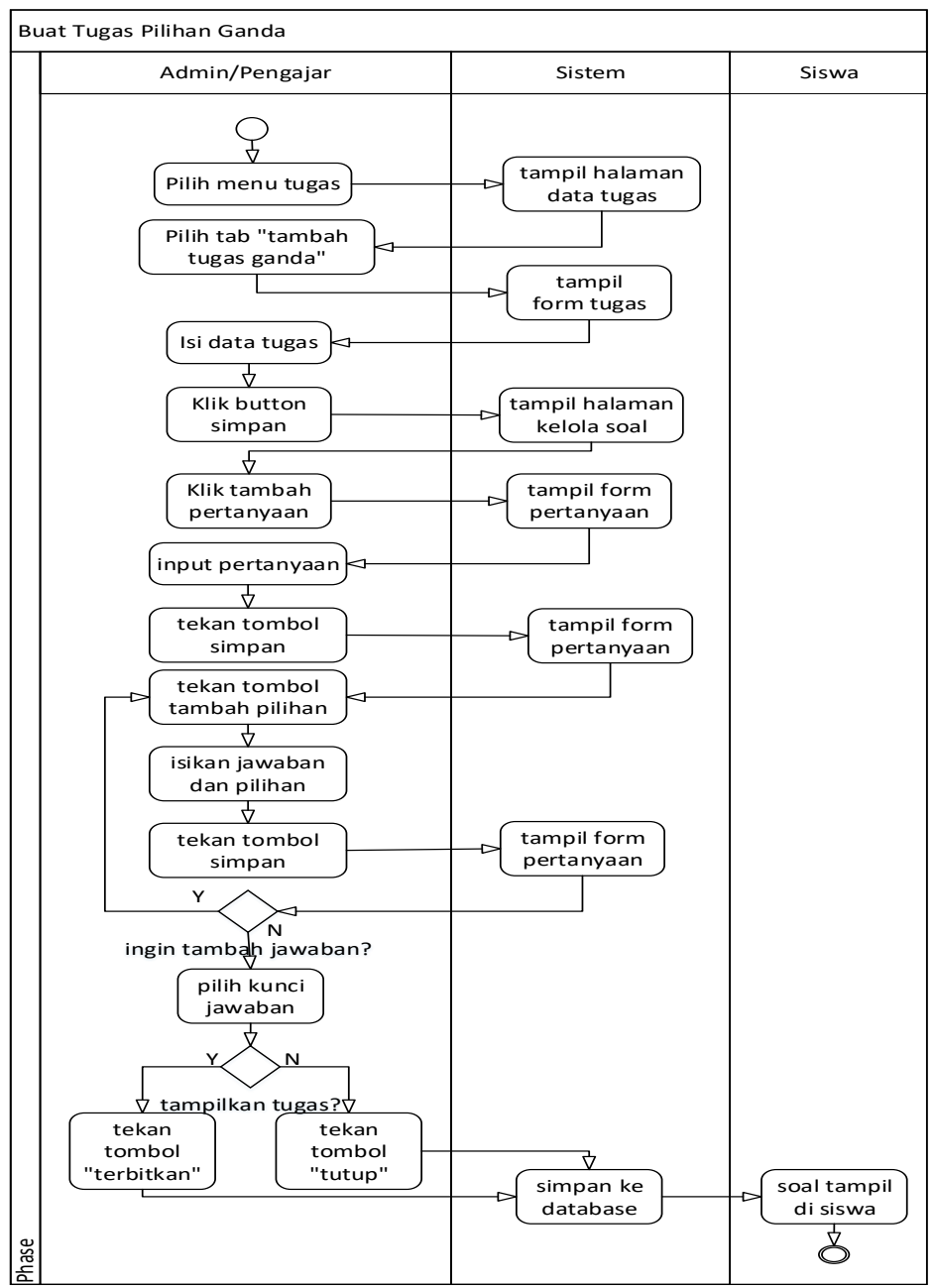

Gambar 8. Activity Diagram Buat Tugas Pilihan Ganda 
Pengajar atau admin terlebih dahulu masuk pada menu tugas, kemudian sistem akan menampilkan halaman data tugas. Pengajar atau admin memilih menu tab tambah tugas pilihan ganda, lalu sistem akan menampilkan form tugas. pengajar atau admin menginputkan data tugas berupa judul tugas, deskripsi singkat, pilihan jenjang pendidikan tugas, durasi waktu pengerjaan tugas yang nantinya akan berjalan mundur ketika siswa mulai mengerjakan jika sudah maka admin atau pengajar menekan tombol simpan. Selanjutnya sistem akan menampilkan halaman kelola soal. Ketika tugas telah selesai dibuat, selanjutnya adalah menginputkan soal atau pertanyaan. Admin atau pengajar menekan tombol tambah pertanyaan, maka sistem akan menampilkan form pertanyaan. Kemudian mengisikan soal atau pertanyaan jika telah selesai admin atau pengajar dapat menekan tombol simpan. Sistem akan tetap berada di form pertanyaan, selanjutnya admin atau pengajar menekan tombol tambah pilihan. Pilihan disini merupakan pilihan jawaban yang tersedia dari pilihan jawaban a hingga e. Lalu menginputkan jawaban dari pilihan tersebut dan tekan tombol simpan, maka sistem akan menampilkan form pertanyaan kembali. Ulangi langkah menambahkan pilihan hingga pilihan lengkap hingga pada pilihan. Jika pilihan jawaban telah lengkap, maka dapat memberikan kunci jawaban disetiap pertanyaan. Setelah semua diinputkan tugas dapat diterbitkan untuk dapat dilihat dan dikerjakan oleh siswa, atau ditutup untuk tidak dapat dilihat dan dikerjakan oleh siswa. Lalu tugas dapat disubmit dan tersimpan pada database.

Berikut adalah activity diagram untuk membuat tugas dengan jenis essay yang dilakukan oleh pengajar ataupun admin tertera pada Gambar 9. Admin atau pengajar terlebih dahulu masuk pada halaman tugas, kemudian sistem akan menampilkan halaman tugas. Selanjutnya admin atau pengajar memilih tambah tugas essay, lalu sistem akan menampilkan form tugas. Admin atau pengajar mengisikan data tugas dan mengklik tombol simpan. Sistem akan menampilkan kelola soal, kemudian Admin atau pengajar menambahkan data pertanyaan dan menekan tombol simpan. Selanjutnya memilih tugas untuk diterbitkan atau tidak, sistem akan menyimpan pada database.
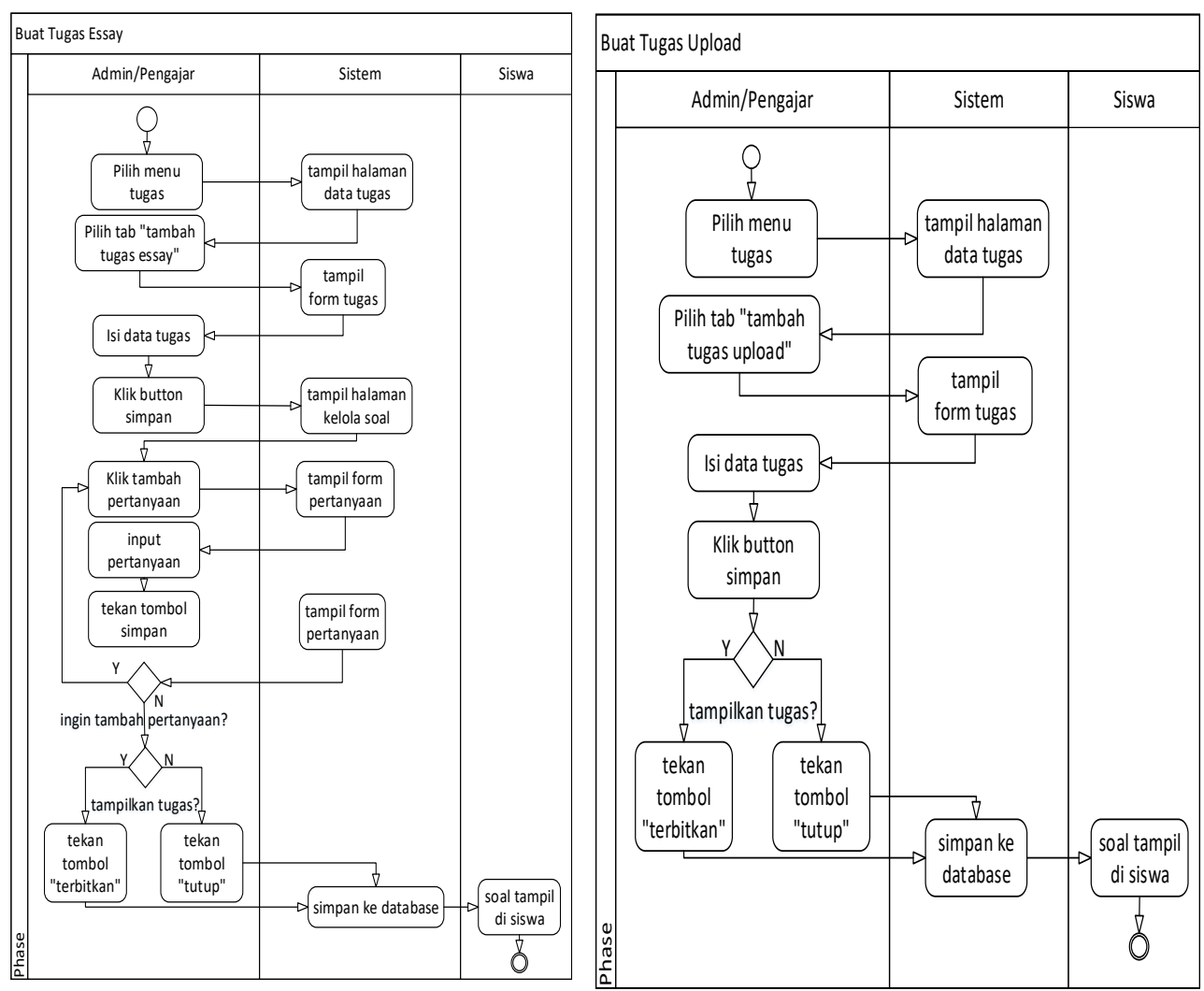

Gambar 9. Activity Diagram Buat Tugas Essay dan Upload

Berikut pada Gambar 9 juga merupakan activity diagram untuk membuat tugas dengan jenis upload yang dilakukan oleh pengajar ataupun admin pada Aplikasi E-Learning Lembaga 
Bimbingan Belajar Gold Generation Berbasis Website. Tugas upload merupakan tugas yang dikerjakan oleh siswa pada file dengan format word/pdf/ppt, dll.

Berikut pada Gambar 10 adalah activity diagram untuk mengerjakan tugas yang telah diterbitkan pada sistem yang dilakukan oleh siswa pada Aplikasi E-Learning Lembaga Bimbingan Belajar Gold Generation Berbasis Website.
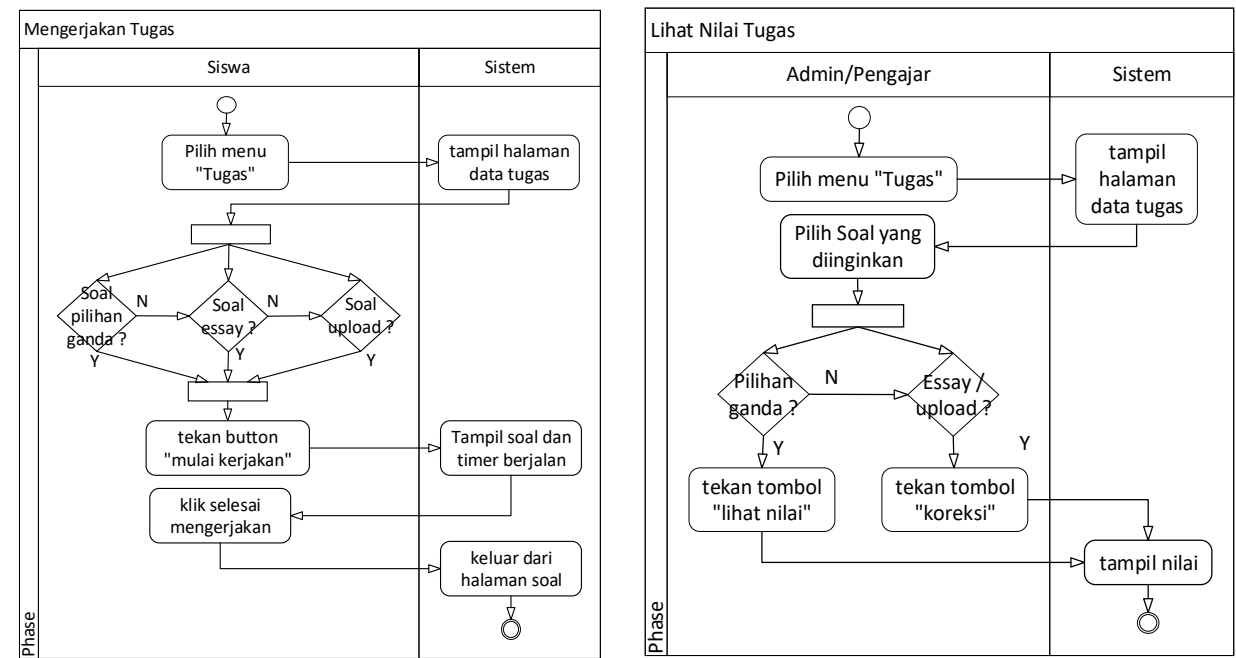

Gambar 10. Activity Diagram Mengerjakan Tugas dan Lihat Nilai

Pada gambar tersebut juga ditampilkan activity diagram untuk melihat nilai setiap siswa. Nilai hanya dapat dilihat oleh pengajar dan admin pada Aplikasi E-Learning Lembaga Bimbingan Belajar Gold Generation Berbasis Website. Nilai pada soal pilihan ganda akan diakumulasi secara langsung oleh sistem. Sedangkan nilai untuk essay dan upload merupakan penilaian dari pengajar itu sendiri.

Berikut pada Gambar 11 adalah activity diagram untuk eksport dan mencetak nilai tugas yang dilakukan oleh pengajar ataupun admin pada Aplikasi E-Learning Lembaga Bimbingan Belajar Gold Generation Berbasis Website.

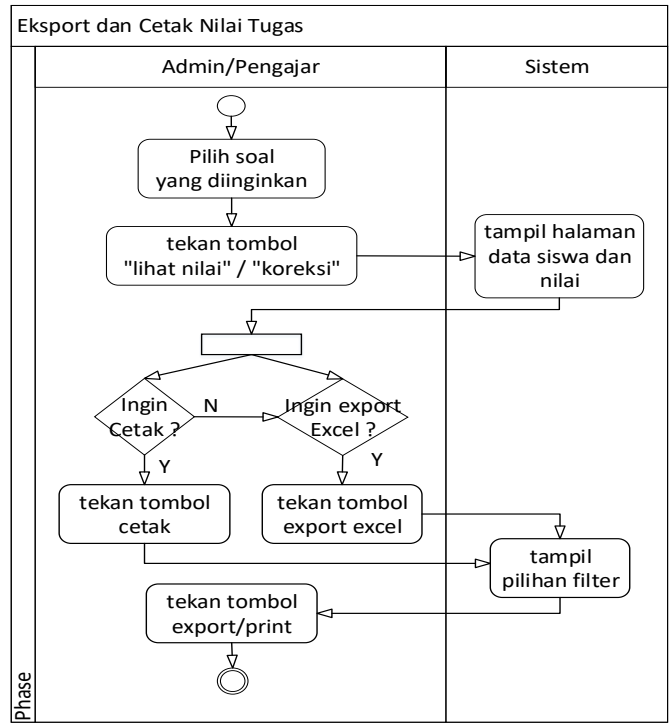

Gambar 11. Activity Diagram Eksport dan Cetak Nilai Tugas

Pengajar atau admin memilih soal yang diinginkan kemudian menekan tombol lihat nilai atau koreksi, maka sistem akan menampilkan data siswa dan nilai. Kemudian memilih action untuk cetak maka menekan tombol cetak dan export excel untuk mengeksport ke file excel. Selanjutnya sistem akan menampilkan filter dan dapat mengeksport atau print file. 


\section{HASIL DAN PEMBAHASAN}

Berdasarkan perancangan yang telah dibuat, hasil yang didapatkan sebagai berikut :

\subsection{Tampilan Halaman Beranda Admin}

Pada gambar 12 merupakan tampilan halaman beranda untuk admin pada Aplikasi E-Learning Lembaga Bimbingan Belajar Gold Generation Berbasis Website. Pada halaman tersebut terdapat akumulasi total jumlah siswa, pengajar, siswa yang pending, dan pengajar yang pending. Selain itu terdapat riwayat login pengguna.

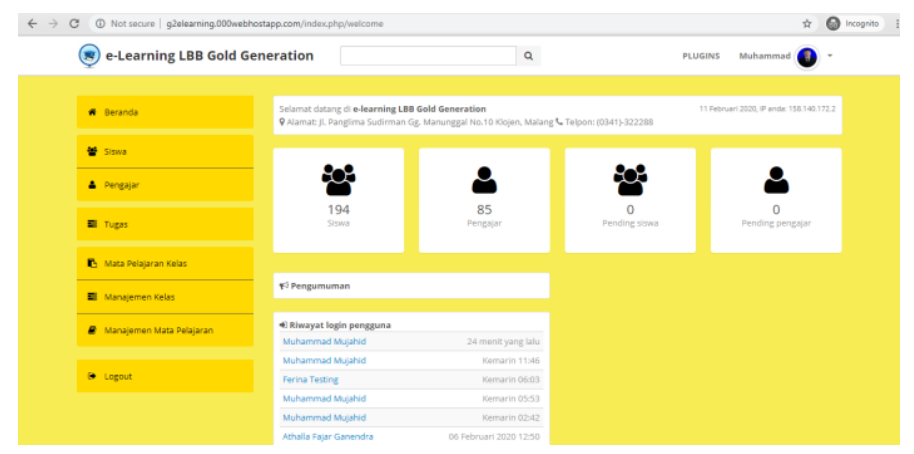

Gambar 12. Tampilan Halaman Beranda Admin

Seluruh halaman pada admin akan tampil menu sidebar di sebelah kiri. Menu sidebar terdiri dari menu beranda, siswa, pengajar, tugas, mata pelajaran kelas, manajemen kelas, manajemen mata pelajaran, dan logout.

\subsection{Tampilan Halaman Tambah Jadwal}

Gambar 13 merupakan halaman tambah jadwal pengajar. Jadwal ini dapat ditambahkan oleh pengajar dan admin. Jika admin ingin menambahkan, maka admin harus masuk pada menu pengajar terlebih dahulu untuk memilih pengajar mana yang akan ditambahkan jadwalnya.

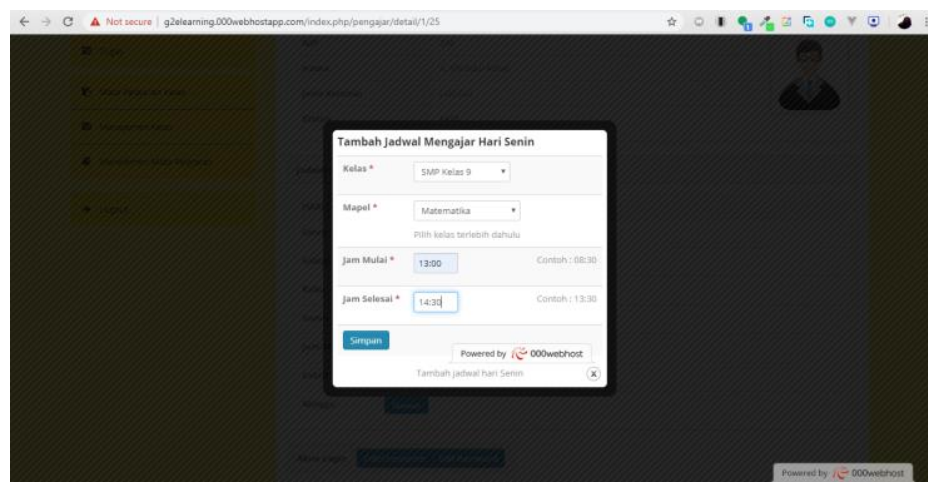

Gambar 13. Tampilan Halaman Tambah Jadwal

\subsection{Tampilan Halaman Tambah Tugas}

Gambar 14 dibawah ini merupakan halaman tambah tugas pilihan ganda pada Aplikasi ELearning Lembaga Bimbingan Belajar Gold Generation Berbasis Website. Halaman ini berguna untuk menambahkan tugas dengan jenis pilihan ganda dengan beberapa field yang harus diisi pada form seperti yang bisa dilihat pada gambar dibawah ini yaitu judul, mata pelajaran yang akan ditugaskan, kelas yang merupakan jenjang untuk tugas tersebut, info berupa keterangan singkat tentang tugas yang akan diberikan serta durasi pengerjaan tugas. Tugas dapat ditambahkan oleh pengajar atau admin. 


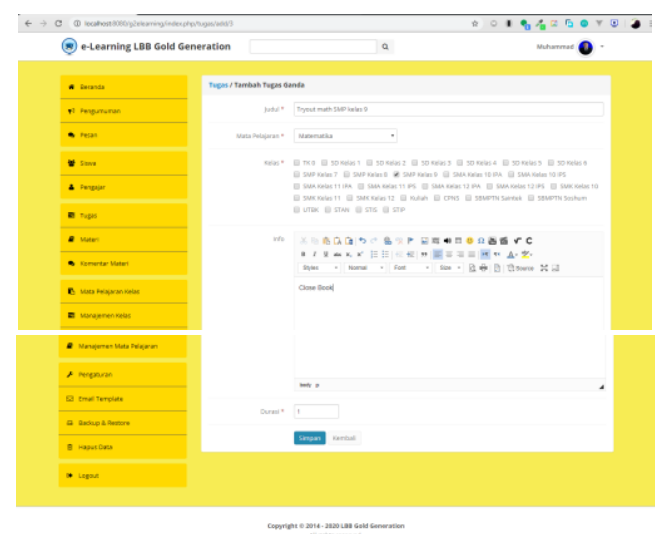

Gambar 14. Tampilan Halaman Tambah Tugas

\subsection{Tampilan Halaman Tambah/Buat Pertanyaan}

Gambar 15 adalah tampilan halaman tambah atau buat pertanyaan pada Aplikasi E-Learning Lembaga Bimbingan Belajar Gold Generation Berbasis Website. Halaman ini adalah tempat bagi admin atau pengajar membuat pertanyaannya baik jenis soal pilihan ganda, essay maupun upload.

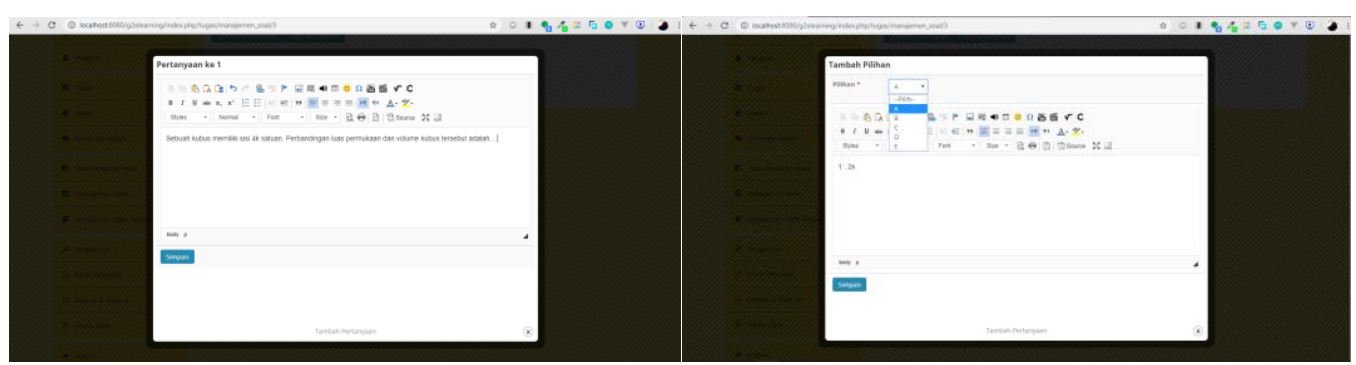

Gambar 1514. Tampilan Halaman Tambah/buat Pertanyaan

Pengajar dan admin dapat menginputkan soal pada text area yang telah disediakan. Selain itu terdapat tools matematika dengan simbol-simbol khusus matematika. Serta dapat menginputkan soal berupa gambar dan video. Gambar 15 adalah halaman tambah pilihan jawaban. Halaman ini adalah tempat bagi admin atau pengajar menambahkan pilihan-pilihan jawaban dari soal-soal yang telah dibuat. Halaman ini hanya ada pada soal jenis pilihan ganda dengan pilihan jawaban dengan rentang A hingga E. Cara menambahkan jawaban tiap pilihan dengan mengisikan memilih huruf pilihan jawaban kemudian mengisikan jawaban pada text area, setelah selesai klik simpan. Lakukan kembali pada huruf pilihan jawaban yang lain.

\subsection{Tampilan Halaman Tugas Siswa}

Pada Gambar 16 adalah tampilan halaman tugas pada akun siswa. Halaman ini berisi tugas-tugas yang tersedia untuk dikerjakan oleh siswa. Semua jenis soal baik ganda, essay dan upload memiliki tampilan yang sama.

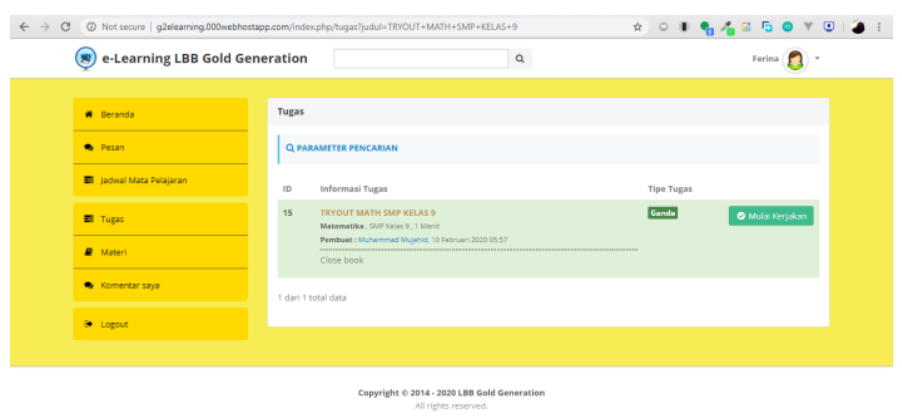

Gambar16. Tampilan Halaman Tugas Siswa 


\subsection{Tampilan Halaman Mengerjakan Tugas}

Berikut adalah tampilan halaman mengerjakan tugas pada akun siswa. Secara garis besar, semua jenis atau tipe soal baik pilihan ganda, essay maupun upload memiliki tampilan yang sama.

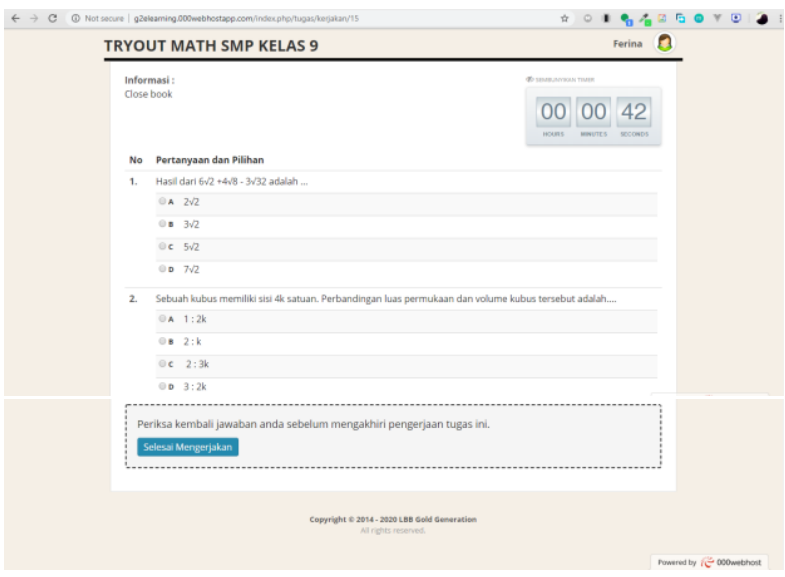

Gambar 1715. Tampilan Halaman Mengerjakan Tugas

\subsection{Tampilan Halaman Lihat Nilai Tugas}

Pada Gambar adalah tampilan halaman lihat nilai tugas pada Aplikasi E-Learning Lembaga Bimbingan Belajar Gold Generation Berbasis Website. Halaman ini berfungsi untuk melihat nilai para siswa yang sudah mengerjakan soal yang dibuat untuk mereka. Pengajar atau admin dapat melakukan reset tugas, sehingga siswa dapat mengerjakan ulang tugas mereka dan nilai berubah menjadi nol kembali.

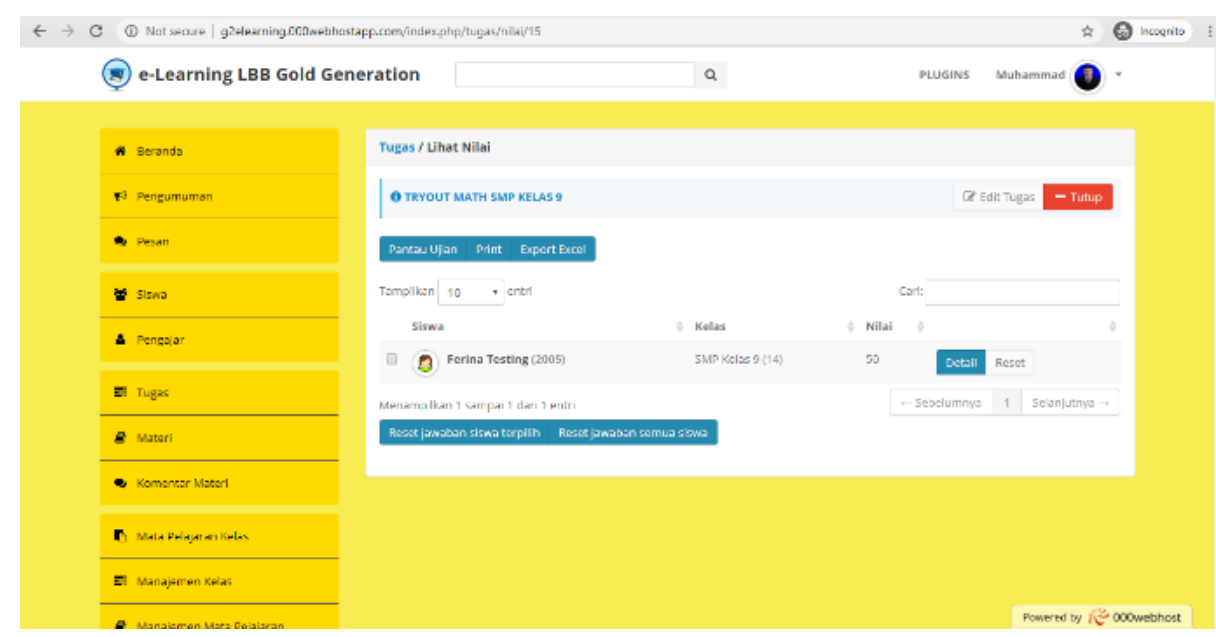

Gambar18. Tampilan Halaman Lihat Nilai Tugas

\section{SIMPULAN}

Dengan pembuatan Aplikasi E-Learning Lembaga Bimbingan Belajar Gold Generation Berbasis Website menggunakan metode Rapid Application Development (RAD) memudahkan admin lembaga, pengurus lembaga dalam mengelola data-data yang ada pada Lembaga Bimbingan Belajar Gold Generation. Serta memudahkan pengajar dalam memberikan tugas kepada siswa, dan melatih siswa dalam manajemen pengerjaan tugas melalui timer pada pengerjaan tugas pilihan ganda dan essay. 


\section{SARAN}

Aplikasi E-Learning Lembaga Bimbingan Belajar Gold Generation Berbasis Website masih diperlukan pengembangan pada fitur pembagian jenis pertanyaan berdasarkan mata pelajaran untuk kategori Tryout, sehingga lebih memudahkan admin lembaga dalam mengelola nilai Tryout para siswa.

\section{DAFTAR PUSTAKA}

1] Muthmainnah, Fajriana, and D. Siska, "Pemanfaatan Teknologi Informasi Untuk Meningkatkan Kualitas Pembelajaran," TECHSI - J. Tek. Inform., vol. 9, no. 2, pp. 65-77, 2017.

[2] Musrifah, "Implementasi Teknologi Informasi Menggunakan Human Organization Technology (HOT) Fit Model Di Perpustakaan Perguruan Tinggi,” J. Ilmu Perpust. dan Inf., vol. 2, no. 2, pp. 222-242, 2017.

[3] D. Ariani, "Komponen Pengembangan E-Learning," J. Pembelajaran Inov., vol. 1, no. 1, pp. 58-64, 2018.

[4] D. Citereup, "Pemanfaatan Teknologi Informasi Dan Komunikasi Dalam Pembelajaran Bagi Para Guru Smpn 2 Kawali Desa Citeureup Kabupaten Ciamis," vol. 4, no. 1, pp. 5962, 2015.

[5] A. Sanova, "Learning Management System (LMS) Sebagai Aplikasi Pengembangan Materi Interaktif Pokok Bahasan Daur Biogeokimia Berbasis Computer Assisted Instruction.," Chempublish J., vol. 3, no. 1, pp. 21-31, 2018.

[6] P. Permana, "Efektivitas Penerapan Learning Management System (Lms) Dalam Meningkatkan Kemampuan Menulis Mahasiswa Bahasa Jerman," Allemania, vol. 2, no. 2, pp. 136-151, 2013.

[7] N. S. Hanum, "Keefetifan e-learning sebagai media pembelajaran (studi evaluasi model pembelajaran e-learning SMK Telkom Sandhy Putra Purwokerto)," J. Pendidik. Vokasi, vol. 3, no. 1, pp. 90-102, 2013.

[8] U. N. Medan, "Layanan Pembelajaran Berbasis E-Learning," Maj. Ilm. Pembelajaran, vol. 6, no. 2, 2009.

[9] S. Aswati and Y. Siagian, "Model Rapid Application Development Dalam Rancang Bangun Sistem Informasi Pemasaran Rumah (Studi Kasus : Perum Perumnas Cabang Medan," Sesindo, pp. 317-324, 2016.

[10] A. Rini and Fatmariani, "Penerapan Metode RAD Pada Sistem Pengajuan Pengambilan Data Penelitian Bankesbangpol Kota Palembang," J. TI Atma Luhur, vol. 4, no. 1, pp. 112, 2017.

[11] H. Hasanah, "TEKNIK-TEKNIK OBSERVASI (Sebuah Alternatif Metode Pengumpulan Data Kualitatif Ilmu-ilmu Sosial)," At-Taqaddum, vol. 8, no. 1, p. 21, 2017.

[12] L. N. Hakim, "Ulasan Metodologi Kualitatif: Wawancara Terhadap Elit," Aspir. J. Masal. Sos., vol. 4, no. 2, pp. 165-172, 2013.

[13] A. Maddeppungeng, I. Suryani, and M. Iskandar, "GEDUNG ADMINISTRASI UNIVERSITAS PENDIDIKAN INDONESIA ( UPI ) KAMPUS SERANG MENGGUNAKAN METODE WORK BREAKDOWN STRUCTURE ( WBS ) DAN KURVA-S,” vol. 4, no. 1, 2015.

[14] M. H. P. Swari and L. P. R. Sugiharto, "Rancang Bangun Media Pembelajaran E-Learning Di Sma Muhammadiyah 1 Denpasar, Bali," J. Teknol. Inf. dan Komput., vol. 5, no. 1, 2019. 